\title{
The Role Of An Effective Student: Case Studies At The University Of Manchester, United Kingdom
}

\begin{abstract}
The acquisition of skills by postgraduate students should be effected as professional learning conducted under their own management. Research students have to take responsibility for managing their own learning and getting a $\mathrm{PhD}$. They are also responsible for determining what is required as well as for carrying it out, and must always keep in touch in regular meetings with the supervisor. The student is the main person responsible for his/her $\mathrm{PhD}$ research. Doing a PhD clearly indicates that this is a student's own research and work. The student is responsible for an original contribution to the subject and for developing a mature, critical knowledge of the subject area and its context. This study is using case study method where three Malaysian PhD students from three major disciplines of study namely arts, science and social science were involved in this research. The objective of this research is to provide better guidelines for effective roles for being a foreign student. As a result, the research had developed the best effective roles in order for students to success in their study.
\end{abstract}

Keyword: Foreign Student, Learning, PhD, Research Student, Supervision, Role, University 